\title{
THE INFLUENCE OF PERSONAL FACTORS OF THE PATIENT, DOCTOR, PAYMENT METHOD AND TYPE OF CLASS TO THE QUALITY AND SATISFACTION OF INPATIENT CARE SERVICES IN DR. MOEWARDI HOSPITAL SURAKARTA
}

\author{
Prima Soultoni Akbar ${ }^{1)}$, Rita Benya Adriani²), Bhisma Murti1 ${ }^{1}$ \\ 1)Masters Program in Public Health, Sebelas Maret University \\ ${ }^{2}$ School of Health Polytechnics, Surakarta
}

\begin{abstract}
Background: The quality of hospital care is an important element in the implementation of healthcare service. The quality which is perceived is an assessment and a form of evaluation of healthcare users. Improvement on healthcare service is continually conducted to enhance the quality of service and patients' satisfaction. The study aimed to explain the influence of patients' personal factors, doctors, payment methods and types of class toward the quality and satisfaction of inpatient care.

Subjects and Method: This was an analytic observational study with crosssectional design. This study was conducted at Dr. Moewardi Hospital, Surakarta, from March to April 2017. A total of 144 subjects were selected by stratified random sampling. Exogenous variables in this study were family income, level of education, length of stay, doctor's salary, the surgeon, type of insurance, and type of class. Endogenous variables were patient's satisfaction and quality of service. The data were collected by a set of questionnaires and secondary data of doctor's working period and salary. Data analyzed by path analysis.

Results: Patient's satisfaction were affected by family income $(b=-0.08 ; \mathrm{SE}=$ $0.48 ; \mathrm{p}=0.093)$, level of education $(\mathrm{b}=-0.44 ; \mathrm{SE}=0.27 ; \mathrm{p}=0.102)$, length of stay $(b=0.19 ; \mathrm{SE}=0.99 ; \mathrm{p}=0.059)$, doctor's salary $(\mathrm{b}=0.02 ; \mathrm{SE}=0.01 ; \mathrm{p}=$ 0.060), doctor's working period $(\mathrm{b}=0.99 ; \mathrm{SE}=0.44 ; \mathrm{p}=0.024)$, type of insurance $(b=0.72 ; \mathrm{SE}=0.32 ; \mathrm{p}=0.027)$, type of class $(b=2.11 ; \mathrm{SE}=0.38$; $\mathrm{p}<0.001)$, and quality of health services $(\mathrm{b}=0.16 ; \mathrm{SE}=0.51 ; \mathrm{p}=0.002)$. Quality of health services were affected by family income $(b=-0.15 ; \mathrm{SE}=0.07$; $\mathrm{p}=0.039)$, length of stay $(\mathrm{b}=0.37 ; \mathrm{SE}=0.15 ; \mathrm{p}=0.017)$, doctor's working period $(\mathrm{b}=0.13 ; \mathrm{SE}=0.68 ; \mathrm{p}=0.056)$, insurance types $(\mathrm{b}=1.04 ; \mathrm{SE}=0.50 ; \mathrm{p}=$ 0.036), and type of class ( $b=2.24 ; \mathrm{SE}=0.59 ; \mathrm{p}<0.001)$.

Conclusion: Patient's satisfaction are affected by family income, level of education, length of stay, doctor's salary, doctor's working period, type of insurance, type of class and quality of health services. Quality of health services are affected by family income, length of stay, doctor's working period, insurance types, and type of class.
\end{abstract}

Keywords: quality of health services, patient's satisfaction, path analysis

Correspondence: Prima Soultoni Akbar. Masters Program in Public Health, Sebelas Maret University, Jl. Ir. Sutami 36 A, Surakarta 57126, Central Java, Indonesia. Email: primasoultoniakbar@gmail.com.

Mobile: +6285258777994. 